\title{
EDUCATING TO FORGIVE AS AN EXPRESSION OF CONCERN FOR ORDER IN A PERSON'S NATURAL ENVIRONMENT. PART 2: THE NEED FOR FORGIVENESS AND ITS EFFECTS
}

\author{
MICHAE WYROSTKIEWICZ
}

\begin{abstract}
The paper describes the question of forgiveness and its importance in the process of the integral development of the human person. After earlier perceiving and accepting these anthropological premises, we can think of forgiveness as a necessity. The foundations of such thinking are two basic premises. The first of these is the belief in the inevitability of mistakes, therefore, potentially blaming other people. These faults and, on the other hand, harm suffered, disrupt proper interpersonal relationships, and returning to them is possible only through the act of forgiveness. The second premise is the natural need for justice, which is the realization of the naturally desired good by man. The forgiveness should be included into everyone's agenda and be presented as an imperative whose implementation is a condition of one's development, and the initial condition for order in a social environment.
\end{abstract}

Keywords: harm, forgiveness, anthropology, integral development of the human person, human ecology, upbringing, educational space.

\section{INTRODUCTION: CONTEXT END HYPOTHESIS}

The reflection presented in the first part of the study on the sources of the need for forgiveness [1] leaves us no doubt that the experience of evil, especially the harm that it particularly entails, is a difficult and unfavorable experience for man who is naturally good. This is an experience that cannot be ignored and demands our reaction. Unfortunately, the often used methods to "fight against harm", namely revenge and retaliation, are not effective ways to build social order. These actions only seem to present a way to introduce order; they are only an apparent fulfillment of the postulate to return to the natural state in the environment of the human person and their welfare. They are only seemingly ecological actions that apparently improve the conditions for human existence (meaning the perspective of human ecology, where society as a social component plays an important role in the natural human environment [2]). In reality, revenge and retaliation multiply evil. As we have noted, it is completely unnatural for a human person and society, very unfavorable for individual people (especially their integral development) and for relationships among them.

Past evidence leads to the conclusion that if a person has to react to harm and the reaction should not be evil, then one should look for solutions that will benefit the human life environment, and as a consequence, above all for an individual person, which will be in accord with the nature of the human 
person. Therefore, we are talking about a solution that introduces real order into the natural environment of a human person and enables their integral development. According to the suggestion crowning the already mentioned first part of this study [1], forgiveness is the right solution. This statement is the hypothesis (research problem) of the research described here.

\section{METHODS AND AsSUMPTIONS (IN BRIEF)}

The analysis and discussions, which are an essential part of this paper, are intended to verify the above hypothesis. It can also be said that their purpose is to find the above mentioned proper reaction to harm and a justification of the choice made.

The research hypothesis is as follows: the only right action a harmed person can undertake is forgiveness. Although this is undoubtedly not an easy task, and in some cases even very difficult, today's state of humanistic knowledge does not give us the opportunity to find an alternative. Only forgiveness appears to be a suitable tool for restoring natural order into the environment of a person disrupted by the harm that their person experiences, and they are the reference point for these undertaken analyzes.

As stated in the title and mentioned in the introduction, this study is a continuation of what was previously published, so the methods and assumptions are identical for the entire study, which consists of both texts. There is no need to repeat the methodology that is discussed in detail in the first part. In order to preserve the methodological order and the proper sequence of the study, it is worth mentioning that, in line with the assumptions, the inclusion of a reflection on harm and forgiveness in interdisciplinary human ecology is to produce coherent syntheses resulting from the analysis of anthropological texts and facts presented from the point of view of different fields of knowledge dealing with people (primarily psychology and several theological fields). In other words, human ecology is the tool used for organizing this study.

\section{ANALYSIS AND DiscusSiON}

Retaliation and revenge as well as anger and malice against a villain should not be equated with the punishment and compensation of losses or the harm he caused. These realities - under appropriate conditions - are legitimate tools for rebuilding social order. They are beneficial for both society and individuals who were inflicted with injury. This concerns both an injured person and a wrongdoer [3, p. 209-219]. However, these tools cannot guarantee the return of full ecological order into the natural environment of a human person, especially their socio-component. If these tools are able to change the thinking and actions of the former culprit, there is a small chance that they can also influence the victim, especially if the latter inculcates a sense of harm done. This is not about any kind of stubbornness or anger, but about living with the conviction that one is hurt; it means lasting harm written into one's identity - making oneself above all the injured person: it is the recognition that "injured person" becomes their "second name".

Without underestimating the real pain that the injured person carries inside, one cannot fail to pay attention to the fact that - paradoxically - by including the injury in their identity (as outlined above), he can become an unhappy and pretentious man. Distrust of others is characteristic of someone who was wronged [4, p. 11-45] and is seen as a logical reason for judging others as inferior and exalting themselves above them. Since, from the point of view of the victim, people are bad and not trustworthy, and he is different from them, only he is good. In this case, "different" means "better".

The above point of view is a direct path to pride. A very real effect of such thinking is "putting on airs with your justice". Such thinking, marked by pride and its related disregard for others, is in itself a serious obstacle to entering into an ordered relationship with every other person. This very often and in an almost automatic way turns into making one's behavior the only reference point. It is about putting into practice the "philosophy" expressed by the slogan "I want to be the norm" [5]. It is not difficult for us to clearly see selfishness in all of this. Being the opposite of love, which in turn is the principle of a 
real community, selfishness is another factor that destroys a community [6]. In conclusion, we can state that a person who experienced evil and inscribed this injury into his or her identity deprives themselves of many possibilities of living in a real community of persons (communio personarum), which is the realization of law and order in the environment's socio-component and the condition for integral development of people living in this environment.

The potential thoughts and attitudes of the victim indicated above intensify their reluctance towards the wrongdoer and other people. This is another - next to the ones noted above - motive that builds a ruthless circle of wrongs and anger. As it turns out, only rationalizing harm - which will result in recognizing it as a fact belonging to the past that is not important at the moment - founded at the level of reason and feelings cuts them off from this event. This is a good way out of the picture that appears in the above reflection of the "self-perpetuating" system of harm-anger-harm. Although without a doubt this is not easy, it is nevertheless necessary. The only effective antidote for the experienced wrong is forgiveness. What can be done to break the vicious circle of harm and suffering? How can we stop hurting each other from generation to generation? How can we free ourselves from the tyranny of a sense of regret that is connected with the harm suffered? What can we do so that the feeling of harm does not poison our spiritual and mental lives? How can we prevent the victim from repeating the learned pattern of abuse and not become a spontaneous wrong-doer himself? These questions are asked by a psychologist-theologian who researches these issues. He immediately responds that the only way out is to initiate the process of gradually overcoming the sense of hurt, and this will lead to forgiveness. This is the above-mentioned and perceived as necessary homework for integrating the experience of harm. The following reflections will justify this unquestionably correct point of view [7, p. 5-9].

An in-depth reflection on forgiveness shows that it is the ability to attribute proper meaning to the past. In addition, forgiveness is a technique that allows people to live "here and now". Whoever forgives is often stronger than his torturer, because he can go beyond what has happened, freeing himself from experiences that have negatively affected his life [8]. A man who rejects forgiveness deprives himself of all the potential that he can bring into his life.

Searching for analogies that would illustrate the situation of an aggrieved person who did not forgive their wrongdoer, one can refer to staying in a prison in which there is neither full freedom nor the possibility of fully participating in life [5]. Although undoubtedly the victim was forced into his "inner prison" by the wrongdoer, he stays there because he does not want to leave. Being reluctant to forgive is a manifestation of a specific intellectual and emotional ossification. It also appears to be a rejection of knowledge about the dynamism of the human person and interpersonal relationships. Against this background, forgiveness is seen as being open to these existential dimensions.

Continuing the above thoughts, one may hypothesize (risk stating) that remaining not forgiven can be a kind of comfortable situation. The aggrieved person has his proven position and "martyrdom," which in special cases can make him a hero. It almost always presents him as exceptional. Preparing to forgive and the act of forgiveness itself might disrupt such a state.

Forgiveness, or completely being deprived of anger, grief and resentments, is the only possible way to heal relationships between people [9, p. 603-604; 10, p. 393-396]. Until the aggrieved person does not authentically forgive the villain, meaning until he does not stop seeking the possibility of proving that the villain is worse than himself and therefore does not deserve goodness, until that moment there will be no proper relationships (meaning relationships from which goodness will flow), neither between themselves nor the entire society. Misunderstanding and disputes (as mentioned in the first part [1]), by their very nature involve other people standing next to the situation.

It is worth stressing the truth that forgiveness is not exonerating someone who is at fault, but the recognition that although he is a villain and a culprit, he has the right to live life to the fullest; has the right to be treated humanely, in accord with the dignity of a human person. This does not mean that we do not notice (or actually pretend that we do not see) or conceal the evil and harm someone has done; it does not mean giving up the lost good (it is important that justice investigations not be equated with the compensation of wrongs according to the "eye for an eye" principle), but it is a consent to accept a 
criminal as one's brother. Forgiveness means removing the label from someone stating that he is a villain - it means cutting them off from this stereotype and a simple evaluation and guiding the next steps of a man who has committed evil in the past.

Of course, forgiveness is not about declarations or forced behaviors, but about really thinking that the evil experienced is now history, and whoever has done it has the right to live a normal life. It is about such a belief and acting according to it. This means that - as noted - we are talking about acknowledging through reason that the culprit (although he is truly guilty!) is to be treated like any other person from whom no harm has been suffered, including accepting such a state and putting it into practice without any conditions.

In this context, we ought to refer to the teaching of the Catholic Church, which (especially in recent times [11; 12]) draws particular attention to the issue of forgiveness and makes a significant contribution to our reflection on this topic. The way we treat a wrongdoer as described above seems to be expressed by the basic idea of those building their Christian identity as the call to "bear wrongs patiently" and "willingly forgive injuries"; this is the call that the Church's Tradition has included in the canon of the "spiritual works of mercy" [13: 2447]. Mercy, however - as Pope Francis emphasizes is an expression of the fullness of humanity. We are talking about a man who makes an effort to "be like the Father" [11], meaning like the Creator - the One whose "image" is man [14: Gen 1:27]. Mercy is simply divine action that creates order in the world. The "culture of mercy" or forgiveness is the culture closest to mankind [12] and the most ecological. Performing works of mercy, including forgiveness, is the way to kind of create the world anew ("like the Father-Creator"); it is introducing into matter contaminated by evil the invigorating Spirit of God.

Properly understood forgiveness is the first step and a necessary condition for reconciliation, that is, a return to fraternal, community and truly human relationships. Figuratively speaking, we can say that forgiveness is the beginning of our "return to paradise", meaning the state where only good exists. There is no other way to get rid of evil than through a free and intelligent act of being cut off from it. Restoring relationships with others we should begin with seeing positive in them. This is one of the features of every man's identity (which was the starting point of the reflection recorded in the first part of the study [1]). Evil is an affliction that happens to people for various reasons [15]. Focusing on evil is a reductionist action that distorts a person's image and deprives them of their identity. Understanding this is an important step towards forgiveness and, consequently, reconciliation; it is an important moment for the above mentioned rationalization of the harm suffered and the elimination of evil in the world.

Forgiveness, however, is not - as it might seem - only or primarily a cleansing of interpersonal relationships from bad historical experiences. Above all, it is a change in one's own way of thinking - it gives past facts their proper place and meaning. It is optimistic, full of hope and trust, referring to knowledge naturally orienting people towards the good, letting them focus on the present and future; it is entering into the natural, current time space - it is life here and now.

Properly perceived forgiveness is by no means a capitulation or some display of weakness - as might appear in a superficial observation of the matter. On the contrary, it is a courageous personal undertaking based on the rational premises of responsibility and an expression of a desire to live without prejudices against anyone and any situation. It is an expression of a rationalized conviction that good and not evil is the driving force in the world [8]. Evil is an unwanted reality that should be blocked by good; evil should be changed into good. By forgiving, such thinking is confirmed.

It is worth noting that while reconciliation is a process, forgiveness is an act. Although many studies, especially in the field of psychology, social work or spiritual theology, emphasize the time distribution and gradation of forgiveness [4, p. 11-45; 7, p. 5-9], from the point of view of the theory of the human act, it is a concrete act [16, p. 129-132; 17] that often crowns a long and difficult preparatory period. The problem raised here is secondary in the practice of forgiveness. It is worth mentioning, however, that we must be aware that opening up to another person and entering the path of empathy is not yet forgiveness. On the other hand, this knowledge makes us realize that forgiveness is an act (thus 
an action), and this does not mean that it is impossible to return to resentment towards a person who has previously committed evil against us. Even such actions do not exclude sincerity in forgiveness.

Of course, forgiveness is not an easy undertaking - as we have already pointed out. It requires breaking through emotions and other natural consequences of the experienced evil, as we noted earlier. However, this is a necessary point in order to return to truly ecological relationships in the natural environment of the human person. The words of John Paul II, analyzed according to this key, who in the Apostolic Exhortation Reconciliatio et paenitentia speaks of the "joy of forgiveness" [18: 10] can be understood as the joy of radically rejecting evil, which in the act of experienced harm took on a concrete form, now restores the natural conditions for human existence. The forgiver experiences authentic joy because of the fact that his decisions and attitudes make the world a better place.

Recalling this papal document leads us to theology. In this context, it is worth noting that forgiveness means resigning from anger - being something contrary to it. If we remember that it is one of the deadly sins [13: 1866], then we can be happy that we do not commit it. It is worth noting that the Catechism clearly associates it with retaliation and hatred, which are clearly condemned in reference to the teachings of Jesus, who shows us what a fully human life is all about [13: 2262]. In this situation, forgiving someone turns out to be some kind of "self-immolation" that is not only a resignation from a specific action (individual) unfavorable to their development, but also leaving behind a sinful lifestyle and entering the path of goodness, meaning naturalness, that is, law and order, including environmental. Forgiveness, therefore, appears to purify man from non-ecological traces, which are sins - as we have already mentioned.

The act of forgiveness is an internal act of the forgiver, because it is a result of his rational decision and can be externalized. Of course, it requires a lot of prudence to realize and show forgiveness so as not to minimize the wrongdoer (not to let him feel or show that he is worse, or that he is "receiving an undeserved favor"), but to give him a chance to experience this with dignity (otherwise it may turn out that apparent forgiveness is actually a realization of the "forgiver's" egoism). Here, as we already mentioned, we are mostly dealing with emphasizing and maintaining one's dignity. This does not mean that it cannot be publicized. In some cases, it is even necessary that this act of forgiveness not be understood as naivety, and that the pardoned person not interpret it as permission to do further evil. That is why forgiveness - so that it not be naive - should as far as possible be based on the culprit's repentance, the willingness to repair their relationships with others and to break bonds with other evildoers [9, p.603-604].

There are situations in which the culprit does not reflect, repent and change their conduct. This does not mean, however, that the act of forgiveness will be meaningless. Based on the fact that he will not repair social relationships in the way that he could with the help of a contrite culprit, one should not give up. As noted above, forgiveness is not only directed towards introducing order into interpersonal relationships, but also - and perhaps above all, because it is a necessary beginning for all good relationships - for a change of mind and, consequently, the actions of the person who forgives.

As it was often noticed forgiveness is a difficult undertaking. In some cases it even becomes heroic. Undoubtedly, such a statement is not an exaggeration. However, from the point of view of theology whose theses are an important reference point for our reflection within the human ecology trend, which in turn is a tool for organizing this study (as discussed above in Methods and assumptions) - we should not overestimate the heroic dimension of forgiveness. For although it is always an expression of courage, openness and focusing on the good as well as emphasizing the dignity of another person, even if he is a villain, it does not mean this is an extraordinary action. After all, is this not the expression of Jesus' call to love according to his measure [14: Jn 15:12], and also that the righteousness of his disciples be "greater than that of the scribes and Pharisees" [14: Mt 5:20]? In such a situation, forgiveness appears to be an act of justice, like naturally striving for natural relationships between people who in a natural way commit evil, although they inherently strive for good. In this sense, forgiveness becomes natural, necessary and therefore an ordinary element of human life.

Concluding the analyses and discussions about forgiveness, it is worth recalling the words of a scholar who, devoting more than a quarter of a century to the study of this issue, remarked: "For 
centuries, forgiveness has primarily absorbed the thoughts of religious people, especially Christians. However, in the mid-1980, psychologists began to draw attention to the fact that forgiveness can be beneficial to the person forgiving" [21]. Among the detailed theses that are formed in the aftermath of these studies, which are extremely important for this study, we present the following two.

First, people, if they really want to and are properly supported, can forgive the greatest harm done to them. Second, forgiveness is a great good for the forgiver. It gives him or her not only peace, but also security and restores balance into the relationship in which they enter. It is not hard to see that this is nothing other than what is written in the title of this text as "Order in a Peron's Natural Environment". The explorations mentioned above, supported by empirical research, became the premises on which the call to practice forgiveness in the sphere of personal, family, professional, social and state relationships was based. This is the documented path to social and personal development.

\section{CONCLUSIONS}

The above reflections (presented in both parts of the study) clearly show that people who really want what is good (this is their nature and natural aspiration), sometimes (even often) act contrary to this need: they either choose the lesser good, thus rejecting the greater good, or more or less consciously sacrifice it, or choose evil that to them appears to be good. A particular type of evil is harming another human being [20].

After perceiving and accepting these anthropological premises, we can think of forgiveness as a necessity. From the point of view of human ecology, which was an ordering tool in the reflection presented above, the foundations of such thinking are two basic premises. The first of these is the belief in the inevitability of mistakes, therefore potentially blaming other people. These faults and, on the other hand, harm suffered, disrupt proper interpersonal relationships, and returning to them is possible only through the act of forgiveness. This is beneficial not only for those who receive forgiveness, but also for the forgiver. The second premise is the natural need for justice, which is the realization of the naturally desired good by man. Justice combined with the theological thesis that man continually experiences forgiveness from God is not only obligatory, but we also feel the need to give others our forgiveness.

Talking about forgiveness directs our attention to "great injuries" and "big matters". Of course, the size is not an objective measure. It is a relative value, individual and different for each victim. One's distance towards the absolute perception of loss is expressed in the entry here (within quotation marks). It should be emphasized that the above-mentioned reflections refer to everyone, even to a "little forgiveness", which will be the result of a "small harm". The point is that, regardless of its matter and size, only true forgiveness is able to normalize the relationship that harmed them; only forgiveness is a tool for ecological clean-up. This thesis is an expression of a positive verification of the research hypothesis set forth in the initial part of the study.

It is worth paying attention to the fact that every wound, if not healed by forgiveness, can grow into a "serious matter" - ultimately into "a big injury", in other words, a harm perceived to be a great harm by the aggrieved party. No creation of taboo topics, ending discussions and forgetting (sometimes forcefully) about injuries or pretending to forget about them (which ultimately amounts to creating taboo subjects) is an appropriate way to keep good, meaning natural relationships in the human person's environment. Maintaining an ecological order in the environmental socio-component requires forgiveness. If this is missing, there is no chance for bringing about order. As we have shown above, people will always make mistakes, do evil deeds and hurt each other, and they will have to live with this and chose either one of two ways. The first is to accept evil experiences and even nurture them and include themselves in a "personal martyrology" as part of their own identity. The second is to cut themselves off from evil by forgiving. There is no doubt that the second option is appropriate for the human person. This choice is suitable for human nature: it is ecological.

To end this part of the undertaken study and return to the first part of the study on the research about the sense of educating mentioned at the beginning, it cannot be doubted that - if an integrally 
implemented human person is to be on the path of integral development, we must take into account the need for forgiveness. It should be included into everyone's agenda and be presented as an imperative whose implementation is a condition of one's development, and the initial condition for order in a social environment [19]. Educating to forgive is a necessary tool for introducing and maintaining order in the natural environment of a human person.

\section{REFERENCES}

[1] Wyrostkiewicz M. Educating to Forgive as an Expression of Concern for Order in a Person's Natural Environment. Part. 1: Evil and Harm in the Life of a Human Person as the Source of the Need to Forgive. Journal of Vasyl Stefanyk Precarpathian National University, 4 (1) (2017), 133-139. doi: 10.15330/jpnu.4.1.133-139

[2] Wyrostkiewicz M. Human Ecology. An Outline of the Concept and the Relationship between Man and Nature. Wydawnictwo KUL, Lublin, 2013.

[3] Wyrostkiewicz M. The Capital Punishment in Times of Terrorism. Anthropological-social analysis. Teologia i Moralność, 3 (2008), 209-219. (in Polish)

[4] Mellibruda J. Trap of an non-forgiven harm in the psychological aspect. In: Harm and Forgiveness, 2. Wydawnictwo M, Kraków, 2010. (in Polish)

[5] Lachmanová K. The non-forgiveness Prison. Salwator, Kraków, 2012. (in Polish)

[6] Nagórny J. The mission of the Christians in the world. In: World and community, 1. RW KUL, Lublin, 1997. (in Polish)

[7] Augustyn J. Wstęp. In: Harm and Forgiveness, 2. Wydawnictwo M, Kraków, 2010. (in Polish)

[8] Cavaliere R. The Art of forgiveness. Wydawnictwo WAM, Kraków, 2007. (in Polish)

[9] Jasiński A. Forgiveness. In: Encyklopedia katolicka, 16. Towarzystwo Naukowe KUL, Lublin, 2012. (in Polish)

[10] Orzeszyna J. Reconciliation. In: John Paul II. Encyclopedia of moral teaching. Polwen, Radom, 2005. (in Polish)

[11] Francis (pope). Bull "Misericordiae Vultus". Libreria Editrice Vaticana, Città del Vaticano, 2015.

[12] Francis (pope). Apostolic letter "Misericordia et misera". Libreria Editrice Vaticana, Città del Vaticano, 2016.

[13] Catechism of the Catholic Church. Libreria Editrice Vaticana, Città del Vaticano, 1993.

[14] The New American Bible. United States Conference of Catholic Bishops, Washington, 2002.

[15] Wyrostkiewicz M. Why do people sin? Katecheta, 57 (5) (2013), 49-53. (in Polish)

[16] Nowosad S., Wyrostkiewicz M. Human Act. In: John Paul II. Encyclopedia of moral teaching. Polwen, Radom, 2005. (in Polish)

[17] Wyrostkiewicz M. What is Human Act and Why It is Worth Dealing? Katecheta, 56 (10) (2012), 61-63. (in Polish)

[18] John Paul II. Adhortacja "Reconciliatio et paenitentia". Libreria Editrice Vaticana, Città del Vaticano, 1984.

[19] Budnyk O. Educational model of a modern student: European scope. Journal of Vasyl Stefanyk Precarpathian National University, 3 (2-3) (2016), 9-14. doi:10.15330/jpnu.3.2-3.9-14

[20] Vasianovych H., Budnyk O. The Category of freedom in the written heritage of John Amos Comenius and Hryhoriy Skovoroda. Advanced Education, 7 (2017), 85-89. doi: 10.20535/2410-8286.93517

[21] Worthington E.L. Forgiveness changes the world. Charaktery. Magazyn Psychologiczny, 16 (9) (2012), 42 43. (in Polish) 
Address: Michał Wyrostkiewicz, The John Paul II Catholic University of Lublin, 14, Aleje Racławickie, Lublin, 20-950, Poland.

E-mail: m.wyrostkiewicz@gmail.com.

Received: 14.11.2017; revised: 23.03.2018.

Виросткєвіч Міхель. Виховання здатності пробачати як вираження стурбованості щодо упорядкування природного середовища людини. Частина 2: Потреба прощення та іï наслідки. Журнал Прикарпатського університету імені Василя Стефаника, 5 (1) (2018), 142-149.

У статті описується проблема прощення та їі значення у процесі цілісного розвитку людської особистості. Після попереднього вивчення та сприйняття певних антропологічних подожень автор виражає припущення, що прощення - це необхідність. 3'ясовано, що в основі такої думки - два важливі аргументи. Перший із них - це віра в неминучість помилок, тому потенційно ми звинувачуемо інших людей. 3 іншого боку, - ці помилки завдають шкоди, порушують належні міжособистісні стосунки, і повернення до них можливе лише через акт прощення. Другий аргумент це природна потреба людини у справедливості, яка полягає у здійсненні нею природно бажаного блага. Прощення має бути вкдючене до повсяқденного життя кожної особистості і бути представленим як імператив, виконання якого $є$ необхідним для власного розвитку та першочерговою умовою порядку в соціальному середовищі. Автором наголошено на важдивості виховання здатності пробачати один одного у процесі налагодження толерантної взаємодії в освітньому просторі навчального закладу.

Ключові слова: шкода, прощення, антропологія, інтегральний розвиток людської особистості, екологія дюдини, виховання, освітній простір. 